\title{
La imagen intolerable1: Intensidad estética y violencia en el cómic de superhéroes
}

\section{Villordo, Aníbal}

Resumen:

El artículo aborda la temática de la intensidad estética y de la violencia en el cómic de superhéroes. Se analiza como la injusticia encuentra en la utilización de la violencia un medio para la resolución de los conflictos. En este contexto, el espectador asiste a una narrativa cargada de una intensidad estética monstruosa. La violencia gráfica que se posiciona como efectiva para apropiarse del símbolo (el castigo de los malos) constituye una pura ficción; que el lector comprende que no tiene consecuencias en el mundo real.

Palabras clave: violencia - comics superhéroes.

$\left(^{*}\right)$ Licenciado en Ciencia Política por

Cuadernos del Centro de Estudios de Diseño y Comunicación №74

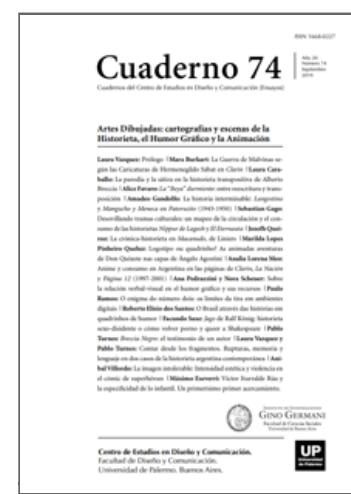

ISSN: 1668-0227

Artes Dibujadas:

cartografías y

escenas de la

Historieta, el Humor

Gráfico y la

Animación

Año XX, Septiembre 2019, Buenos

Aires, Argentina | 256 páginas

descargar PDF

ver índice de la publicación

Ver todos los libros de la publicación

compartir en Facebook

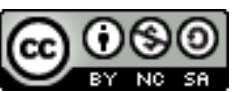

Esta obra está bajo una Licencia Creative Commons Atribución-NoComercialCompartirlgual 4.0 Internacional

la Universidad de Buenos Aires

(FSOC-UBA). Maestrando en Comunicación y Cultura, cohorte VII 2012-2013 (FSOC-UBA). Integrante del Panel de Expertos de la Revista de investigación "Silogismos" CIDE ISSN: 1909-955XE ISSN: 2422-0736. Integrante del grupo de investigación Narrativas Dibujadas, Historieta, Humor Gráfico y Animación de la Carrera de Ciencias de la Comunicación (FSOC-UBA). Docente CBC, Universidad de Buenos Aires.

Introducción Y dijo Dios: no te harás imagen... El resultado: el mundo se llenó de imágenes.

Fue Moisés, según cuentan los escritos bíblicos2, quien recibió la enfática prohibición de parte de Dios de hacerse imagen cualquiera, tanto de lo que hay en los cielos, en la tierra o debajo de la tierra.

Si bien el énfasis de la prohibición no estaba puesto en la hechura de la imagen en sí, sino en la prohibición de adorarla, no obstante el mandamiento deja bastante implícito desde el principio el inmenso poder que las imágenes tienen en la mente de los hombres. 
Tal es la fascinación que desde tiempos inmemoriales el hombre siente por intentar describir, aprehender o representar con trazos, sombras, colores o líneas el universo que le rodea (Gombrich, 2003) aún a riesgo de despertar la ira divina.

A ciencia cierta, no sabemos sí algo de aquella prohibición originaria funcionó, pero las primeras representaciones tímidamente esbozadas comprenden trazos de figuras de animales, que derivaron luego en los de la figura humana, amalgamadas posteriormente en imágenes de seres combinados animal y humano que representaban la encarnación de las fuerzas de la naturaleza, que comenzaron a ser temidas y adoradas por considerar que estábamos a merced de dichas fuerzas arbitrarias a las que la humanidad debía calmar, mas que someter. $Y$ en un momento, los trazos de la figura humana comenzaron a perfeccionarse, a idealizarse, a buscar la robustez y la belleza atribuible a aquellos que estaban por encima del estándar de los simples mortales: es el momento del nacimiento de los héroes, que desafiaron la ira de los dioses intentando devolver a manos de los hombres un destino que les era esquivo cumpliendo, quizás sin saberlo, la sentencia de la serpiente en el Paraíso bíblico cuando dijo a quienes habían perdido su inocencia: "seréis como dioses..."3

Desde ese momento, la imagen de la serpiente paso a ser el ícono dual del mal y la sabiduría, en infinidad de culturas.

Este el germen desde el cual se desplegó el lenguaje mítico.

El mito es, según Barthes, un habla, un habla elegida por la historia y como tal, una forma de habla que puede ser, no solo oral, sino también visual. (Barthes, 2008)

El mito habla de héroes y dioses y su relación con cuestiones éticas como el bien y el mal, la verdad, la justicia y la venganza, y en términos filosóficos, sobre la progresiva normalización de la injusticia (Zizek, 2009).

Con el arribo de la modernidad el mito y la religión intentaron ser desplazadas por una racionalidad técnica cuya operación discursiva es presentar los argumentos científicos como razonables e irrefutables, dotando de una carga valorativa negativa a todos los procedimientos que quedaban por fuera, intentando instalar una dualidad irreconciliable entre hechos comprobables y ficciones.

Sin embargo, esta pretensión totalizadora derivó en un resurgimiento y proliferación de relatos míticos que surgieron por muy diferentes lugares, ocupando diversos espacios:

...pero como una poderosa hidra5, la cabeza que la racionalidad científica pensó cortar al dar el golpe mortal a la irracional religión, derivo en una múltiple proliferación de cabezas que surgieron por lugares inesperados, manteniendo viva esta resistencia del mito ante la pretensión científica. (Villordo, 2015)

Mi hipótesis es precisamente, que el cómic de superhéroes aparece como una de estas posibles reformulaciones del lenguaje mítico y religioso que interpreta la profunda transformación de sentimiento que han experimentado las sociedades de la modernidad tardía, una reconfiguración que es peculiarmente efectiva pues se despliega desde el punto de vista de la imagen, con una intensidad estética muy particular, fascinante a la vez que monstruosa en lo que refiere a la potencia visual de sus imágenes violentas. 
Por tanto, lo que intentaré en este artículo, será reflexionar sobre esta "intensidad estética" del cómic referida principalmente al tópico de la violencia en relación al concepto de imagen intolerable (Ranciere, 2010) y cuales son los mecanismos mediante los cuales esta violencia visual se desplaza desde la dimensión temporal de la visión empírica al ámbito imaginario de la efectiva apropiación del símbolo.

\section{Breve historia}

Siendo el tema de los héroes con poderes sobrehumanos una constante en la imaginación popular en todos los tiempos (Eco, 2009) el cómic de superhéroes aparece como un fenó- meno que desde sus humildes orígenes a fines de la década del 30 en la Norteamérica pos crack del 295 se ha desarrollado en tal forma que contribuyó a modelar el pensamiento occidental posibilitando la construcción de nuevos sentidos en cuanto a la concepción y reformulación del héroe.

Al respecto, Steimberg, refiriéndose a la historieta señala que: "la historieta, que en un comienzo no tenía otras aspiraciones que el impacto como entretenimiento popular y masivo, alcanzó un complejo desarrollo estético ulterior" (Steimberg, 2013, p. 45) mientras que otros autores ubican al cómic como un espacio artístico único y sin igual, considerando como una tragedia estética moderna el abandono de su lectura por parte del público adulto (Morris, 2010) ya que la historieta y el cómic de superhéroes y sus personajes, han realizado un arduo camino que los llevó ha convertirse de una tira oscura y marginal, en estrellas rutilantes del universo cinematográfico en una posmodernidad de saberes precarios, fragmentarios y dispersos, donde se reinventan tramas complejas de villanos y superhéroes acorde a la profunda transformación en la estructura del sentimiento (Harvey, 2008) que interpretan algunos ha sufrido la cultura de las sociedades capitalistas avanzadas, y donde se traspasa continuamente la otrora delineada y prístina línea que separa el bien del mal.

Estas imágenes o cuadros serían una forma de invocar mediante formas líneas y colores, esos misteriosos fantasmas de realidad visual, esa especie de sueños producido por el hombre para los que están despiertos (Gombrich, 2003).

Es interesante el concepto de este autor cuando señala:

...que a muchos de estos sueños producidos por el hombre para los que están despiertos los expulsamos nosotros del reino del arte, tal vez con razón, porque son casi demasiado eficaces como sustitutivos del sueño, sean fotografías de atractivas muchachas o historietas. (Gombrich, 2003, p. 3)

Y es que precisamente por las limitaciones propias de sus orígenes y su destino manifiesto de simple divertimento popular, que se demoró ese desarrollo estético posterior, ya que aparecían presumiblemente como demasiado eficaces como sustitutivos del sueño, principalmente por el contexto social e histórico de su surgimiento, y por encarnar la idea de recuperación del sueño americano6 en el caso de Superman o de la búsqueda de justicia en el caso de Batman, siendo portadores a la vez que depositarios de una serie de evocaciones que priorizaban la apropiación del símbolo por sobre otro tipo de desarrollo artístico mas complejo.

Esta narrativa, fue vehiculizada en un formato con una estética muy particular, clásica en sus comienzos, y que referenciaba los lineamientos tradicionales del bien y del mal, no solo en la narración sino también en la estética: los superhéroes, semejantes a aquellas esculturas griegas que idealizaban en búsqueda de la perfección del ser 
humano; los villanos, estereotipos de mafiosos urbanos conforme al clima de época o humor social, y seres grotescos y visualmente desagradables a manera de las antiguas gárgolas demoníacas que guardaban amenazantes la fachada de los templos medievales.

El resurgimiento de las imágenes "El mundo entero coincide en la adoración al sol..." Abby Warburg

Habida cuenta de que la sociedad occidental moderna necesita de la recuperación y reconfiguración del relato mítico mediante el cual es posible traslucir un fondo común de pensamientos, creencias y acciones, en definitiva, el imaginario mediante el cual nos apropiamos del símbolo detrás de la imagen, en definitiva "podemos entrever ya los contornos de la iconología, que estudia la función de las imágenes en la alegoría y el simbolismo, y su referencia a lo que podría llamarse el invisible mundo de las ideas" (Gombrich, 2003, p. 6). Este resurgir cíclico de algunas características icónicas similares en la imagen del héroe durante distintas épocas y culturas diferentes de la historia es lo que se denomina la "imagen superviviente" (Didi-Huberman, 2009) es decir imágenes que en distintos tiempos y culturas resurgen y se reconfiguran en forma permanente, como es el caso, por ejemplo, de la serpiente, o la adoración al astro rey a través de la imagen del disco solar.

En el caso particular de los superhéroes de la primera hora bastaría con remontarnos al arte del período de la Grecia clásica para rastrear la similitud entre ambos.

Analizando visualmente la fisonomía que toman las figuras idealizadas del arte clásico y comparándolas con las imágenes de los primeros superhéroes, podemos establecer una línea de continuidad estética que emparejaría en un primer momento el bien con lo bello y el mal con lo feo.

En un primer momento, la imagen del superhéroe moralmente bueno, que no buscaba el realismo alcanzado en desarrollos posteriores, exageraba los rasgos físicos en contraste con el ciudadano del común, bajo los lineamientos de la belleza clásica: mentón cuadrado, pecho inflado, abdomen marcado, rostro amable a la vez de presencia intimidante. (Ver Figura 1)

Es decir existe una imagen concordante entre ética y estética, en los pares belleza-bondad en el caso de los superhéroes clásicos y fealdad-maldad en el caso de los súper villanos, por lo que en trabajos anteriores he definido esta correlación como "imagen lineal aquella que empareja súper héroe y súper villano en su ética con su correspondiente estética e imagen contradictoria aquella en donde una de estas características se ha invertido" (Villordo, 2012).

Este emparejamiento que señalo aquí desde lo estético y filosófico, recibió además un refuerzo institucional, como explicaré más adelante cuando me refiera al papel que desempeñó la censura en el desarrollo del cómic.

Ya que Didi-Huberman señala que:

...las imágenes forman parte de lo que los hombres se inventan para registrar sus temblores de deseo o de temor y sus propias consumaciones, saber mirar una imagen es poder discernir el lugar donde arde, poder discernir el lugar donde su eventual belleza reserva un sitio a una señal secreta, una crisis no apaciguada, un síntoma. (Didi-Huberman, 2009) 
...no podemos analizar el surgimiento de la imagen icónica del superhéroe, por fuera del contexto de la crisis no apaciguada en donde se origina, la fisura sensible por donde resurge la imagen superviviente de la cual es síntoma.

Norteamérica, fines de la década del 30, surge quien es, según el consenso de autores referentes a la temática, uno de los emblemas del superhéroe: Superman7 .

Como vimos anteriormente, sus características fisonómicas se pueden rastrear hasta la imagen del período de los héroes de la Grecia clásica.

Pero aún podemos ver más: los colores azul y rojo de su traje, remiten a los colores emblemáticos del país adonde arriba como huérfano interestelar, y en donde puede desarrollar su vida como un humano mas, luego de que fuera encontrado siendo un bebe por el matrimonio Kent, humildes granjeros del pueblo de Smalville, en Kansas City.

También el planeta de donde proviene, Kriptón, destruido por un cataclismo ¿científico? evoca la Norteamérica a la que llega, sobrellevando las trágicas consecuencias del crack del 29, una de las mayores crisis financieras y sociales de la historia, y evoca el temor que en aquellos días la sociedad tenía a un desarrollo de la ciencia que se saliera de control.

Si ahondamos mas, veremos ya no una crisis en particular, sino la crisis del hombre en general en una sociedad tecnológica capitalista, donde el ciudadano vulgar necesita de un héroe positivo: "en una sociedad de este tipo, el héroe positivo debe encarnar, además de todos los límites imaginables, las exigencias de potencia que el ciudadano vulgar alimenta y no puede satisfacer" (Eco, 2008, p. 226).

Por la misma época y en el mismo país, surge Batman8, el encapotado justiciero, quien resuelve tomar en sus manos la justicia que se les escapa a los agentes de la ley, un auxiliar vigilante en las sombras en medio de un contexto social de crisis.

Italia, segunda mitad de la década del 50, la ciudad de Milán experimenta un boom económico, que originó una masiva inmigración del campo a la ciudad.

Las reseñas históricas señalan que, en poco más de una década Italia se había convertido en un país industrializado, una transformación económica tan radical que ya a principios de la década del 60 se hablaba del milagro italiano.

Sin embargo la percepción de los obreros no era de milagro sino de explotación con el agravante que la ciudad se encontraba cercada por el accionar del crimen organizado.

Es muy posible que, la convulsionada mezcla de este ambiente, haya servido de inspiración y modelo para que las hermanas Giussani9 dieran forma a la figura del famoso antihéroe de estética sombría, Diabolik10 (Ver Figura 2) quien a mi entender se plasma en el imaginario colectivo como un vengador en contra del sistema explotador de aquel momento. Estas historias finalmente trascienden el contexto de lo local para apropiarse de algún tipo de símbolo más amplio del orden de lo universal, y es sabido como al colectivo humano le gusta participar de un sentimiento que se presuma como universal. 
Saber mirar estas imágenes (Didi-Huberman, 2009) es entender la necesidad de una iconografía propagandística que potencie la credibilidad en la recuperación del sueño americano (Superman), o en la posibilidad de una supra justicia (Batman), o en la venganza de un ladrón espectacular en contra de un sistema social y financiero explotador y opresivo (Diabolik) en definitiva, en la necesidad de un ser superior o heroico que vela por nuestros intereses, nos defienda y nos vengue del mal, la reconfiguración de una creencia casi religiosa. Y como parte del relato mítico y religioso en todas las culturas es, precisamente no solo la recompensa de los buenos sino también el castigo de los malos, el cual es generalmente inseparable de la idea de algún tipo de juicio, ejecutado violentamente.

Es en este contexto de crisis no apaciguada en el que el superhéroe surge que la violencia deviene como una de las características específicas del cómic: no existe cómic de superhé- roes, si no hay violencia en su desarrollo y resolución del conflicto.

Los compartimentos argumentativos clásicos de la primera hora, son: una persona generalmente débil o despreciada por sus pares recibe, generalmente por algún tipo de accidente o manipulación científica, poderes sobrehumanos, oculta su identidad generalmente bajo un traje visualmente llamativo, se dedica a combatir el crimen o los males de la humanidad cualesquiera que estos sean, pero esto solo puede resolverse por medio de la mas pura violencia.

Si el Estado es quien tiene el monopolio legítimo de la violencia (Weber, 1919) el superhéroe es quien tiene el monopolio privado de una violencia superlativa que puede utilizar a su antojo en base a su propio código ético súper heroico que incluiría una justicia mas del tipo inscrita en naturaleza u ontológica que en un primer momento coincide con las leyes de la sociedad a la que auxilia.

Esta tensión, es precisamente, el nudo argumentativo de la mayoría de los cómics y películas de superhéroes recientes.

Siguiendo esta línea de razonamiento, es que entiendo a la imagen violenta en el contexto del cómic como una necesidad estética en la búsqueda de la normalización de la injusticia y el castigo de los malos.

El papel de la censura

Reforzando estas cuestiones referentes al emparejamiento estético bondad-maldad entre héroes y villanos y la utilización de la violencia en las imágenes del cómic, no puedo dejar de mencionar el papel que desempeñó la censura referente a esta temática, a través del "Comics Code Authority".

Esta entidad fue creada por la Asociación de Revistas de Cómic como medio de autocensurarse, luego de que la campaña en contra del género promovida principalmente por el psiquiatra Fredick Wertham con su obra "The Seduction of Inocent" (1954) hiciera impacto en la opinión pública y fuera retomada por la comisión de delincuencia juvenil del Senado de los Estados Unidos.

En esta obra se describían y denunciaban las representaciones explícitas y encubiertas de violencia, sexo, consumo de drogas y otra temáticas adultas dentro de los cómics de crímenes en las historias del cómic con temas referidos a la delincuencia, el horror y aún los superhéroes que, siempre según este autor, corrompían a 
los niños quienes imitarían supuestamente dichos comportamientos siendo ello una de las causas del aumento de la delincuencia juvenil.

Ante la presión de la opinión pública y antes de que el gobierno norteamericano tomara en sus manos la censura, los editores de revistas decidieron autocensurarse creando la referida CCA, cuyo código limitaba la representación de la violencia, las imágenes sexuales, el imaginario del mal, la delincuencia y de los representantes de la ley.

Al observar la lista de los puntos principales del código, vemos que se refuerza, ya de una manera institucional, el emparejamiento de la belleza con el bien y la fealdad con el mal, con la creación de los estereotipos de héroes y villanos que marcaron fuertemente el imaginario occidental, aún después de la caída en desuso del código de la CCA.

Más allá de que el código señalaba que el bien siempre debía triunfar sobre el mal, que los delincuentes nunca debían ser presentados en forma que despierten simpatía y las autoridades de manera que nunca inspiren desconfianza, se ponía énfasis en la prohibición de utilizar imágenes de excesiva violencia.

La tortura, el sadismo, el innecesario uso de armas, los crímenes sangrientos, la depravación, la lujuria, la seducción, la violación, la desnudez, la obscenidad, la utilización de símbolos indeseables, el lenguaje vulgar o soez, estaba directamente prohibido.

También se prohibía abordar temáticas como la licantropía11, el vampirismo12, zombis y muertos vivientes.

Es muy interesante que, en la actualidad, las series televisivas de mayor éxito son precisamente las que tratan sobre estos tópicos, o una combinación de todas ellas.

Con el tiempo, principalmente a partir de la década del 70, el uso del código cayó en desuso, aunque algunos cómics siguieron adhiriendo al mismo.

Es posible que una sociedad que se vio expuesta a las crudas imágenes de la guerra de Vietnam, comenzara a reformular su relación con las imágenes y la violencia.

La imagen intolerable

¿Qué es lo que vuelve intolerable una imagen? En principio la cuestión parece preguntar tan solo cuales son los rasgos que nos vuelven incapaces de experimentar una imagen sin experimentar dolor o indignación. Pero una segunda pregunta aparece enseguida envuelta en la primera: ¿es tolerable hacer y proponer a la vista de otros tales imágenes? (Ranciere, 2010, p. 99)

Analicemos la siguiente escena: una vieja y derruida casa en un barrio marginal, gente de mala vida fumando y bebiendo, contando pilas de dinero mal habido producto de las drogas y la extorsión, envueltos en la niebla de un humo inespecífico.

De repente, se abre la puerta de la habitación y aparece una niña. 
Su edad: quizás 12 años. No es una niña común: se encuentra vestida con un traje violeta ceñido al cuerpo, máscara y peluca de igual color.

Los guantes gruesos, cubren las manos de una niña en edad escolar.

Pero sus manos no portan útiles, libros, ni lápices de colores, sino afiladas katanas13, cuchillos, y revólveres.

Comienza la matanza: la sangre a borbotones empapa todo el lugar, piernas, brazos y cabezas caen al suelo mientras ella sonríe cínicamente.

Quien observa la escena, participa de esa dualidad de horror y satisfacción.

Un despliegue de sadismo inusitado, muy difícil de contemplar: ella es Hit Girl...la niña golpeadora, la niña asesina, la vengadora enmascarada (Ver Figura 3).

El espectador, embargado, por la "intensidad estética de un espectáculo monstruoso" (Ranciere, 2010) participa de esta danza sangrienta de mutilaciones, sin experimentar ningún remordimiento: ¿cómo es esto posible?: ¡solo porque estamos en el ámbito del cómic, en el mundo de los superhéroes!

Imaginemos por un momento, si nos tocara contemplar esta sangrienta imagen en nuestra vida real y cotidiana, cuales serían las implicaciones psicológicas y éticas que esto tendría. Mas aún, contemplarlo en una ficción cinematográfica más realista sería bastante traumático... ¿que es entonces, lo que diferencia a la imagen del cómic que permite asimilar y consumir estas imágenes tan explícitas de violencia?

Como primera medida, debemos atender a que, como señala Ranciere al reflexionar sobre la famosa foto de "La niña y el buitre"14 una imagen jamás va sola, sino que pertenece a cierto dispositivo de visibilidad que regula el estatuto de los cuerpos, y define el tipo de atención que merece: la cuestión sería entonces saber el tipo de atención que provoca tal o cual dispositivo. (Ranciere, 2011)

En el caso del cómic de súper héroes, este dispositivo atencional contiene una gran cantidad de códigos y guiños muy particulares que el espectador debe discernir en su relación con las imágenes, guiños que permiten construir fronteras de comprensión psíquica que permiten deslizar la violencia efectiva al ámbito de la apropiación del símbolo, lo que nos permite en términos de Zizek (2009) "hacer como si" fuera posible, algo que sabemos no lo es.

Lo que intento postular aquí es que lo que tiene el cómic desde lo visual es una intensidad estética particular que acrecienta el sentido de irrealidad en tal manera que permite priorizar la apropiación de un símbolo, de carácter generalmente universal o en otras palabras:

"la deducción de lo visible por debajo de lo decible, y la deducción de las significaciones y los afectos por debajo del poder de la acción, una acción cuya realidad es idéntica a su irrealidad". (Ranciere, 2011).

Quizás, y siendo consciente de la enorme distancia del caso, podamos acercarnos al concepto utilizando las palabras de Zizek (2009) cuando se refiere a la experiencia de la Revolución Francesa, la distancia entre los acontecimientos y el símbolo: 
La revolución de un pueblo lleno de espíritu puede tener éxito o fracasar, puede acumular tantas miserias y horrores que un hombre sensato que pudiera promoverla por segunda vez con la esperanza de un resultado feliz jamás se resolvería a repetir el experimento a semejante precio. Pero esa revolución encuentra en los espíritus de todos los espectadores (que no están comprometidos en el juego) una simpatía rayana en el entusiasmo, y que no podía obedecer a otra causa que a una disposición moral del género humano. (Zizek, 2009, p. 69)

Es lo que en su andamiaje teórico Zizek denomina una "denegación fetichista", en donde la auténtica dimensión de lo real no está en la inmediata realidad del acontecimiento violento, sino en lo que les parece real a estos observadores no participantes, y las esperanzas que en ellos despierta como imagen sublime. (Zizek, 2010)

Quizás sea posible entonces que, la "intensidad estética" del cómic funcione como un mecanismo que genera la distancia suficiente entre un acontecimiento visual monstruoso (la imagen violenta) y las esperanzas que ello despierta en el observador no participante (la imagen sublime) que finalmente prioriza la apropiación de un símbolo (la normalización progresiva de la injusticia, por ejemplo) que obedece como hemos visto, a una disposición moral del género humano.

Estos seres súper heroicos encarnan toda la potencia que el ciudadano vulgar no puede satisfacer (Eco, 2008) evocando sentimientos que el ser humano anhela y que puede lograr al menos en la ficción, a través de la violencia: "la ficción sería también una forma de esculpir en la realidad, de agregarles nombres y personajes, escenas e historia que la multiplican y la privan de su evidencia unívoca”. (Ranciere, 2010, p. 55)

Como señala Ranciere:

Pero estos seres ficticios no son menos que seres de semejanza, seres cuyos sentimientos y acciones deben dividirse y apreciarse. La "invención de las acciones" crea al mismo tiempo fronteras y pasajes entre dos cosas: los acontecimientos, a la vez posibles e increíbles, que enlaza la tragedia, y los sentimientos, voluntades y conflictos de voluntades reconocibles y divisibles que propone al espectador. Crea fronteras y pasajes entre el disfrute suspensivo de la ficción y el placer actual del reconocimiento. (Ranciere, 2011, p. 125)

Podemos resumir entonces que, siendo el cómic de superhéroes en mi opinión, una de las "cabezas de la hidra" que resurge en contra de la pretensión del desplazamiento que la modernidad a intentando hacer del mito y la religión, las imágenes en relación con la normalización de la injusticia que encuentran como hilo central y distintivo la utilización de la violencia como principal medio de resolución de conflicto en el cómic, permiten, en término de Zizek, una "denegación fetichista" (Zizek, 2009), en donde el espectador, absorto en el disfrute de un espectáculo de una intensidad estética monstruosa (Ranciere, 2011), puede sin embargo construir fronteras de comprensión psíquica que le permiten comprender que ese despliegue de violencia inusitada no tiene consecuencias en el mundo real, sino que se constituye como una irrealidad (magnificada a través de una intensidad estética muy particular) efectiva para apropiarse del símbolo (el castigo de los malos y la normalización de la injusticia) detrás del acontecimiento visual que sabe de por sí, constituye una pura ficción, "la deducción de lo visible por debajo de lo decible, y la deducción de las significaciones y los afectos por debajo del poder de la acción, una acción cuya realidad es idéntica a su irrealidad”. (Ranciere, 2011) 
1. Refiere al título de un artículo del libro El espectador emancipado de Jaques Ranciere, pág. 85, citado en bibliografía.

2. Libro del Éxodo, cap. 20 ver. 4 - Biblia Reina Valera (1909).

3. Libro del Génesis, cap. 3 ver. 5 - Biblia Reina Valera (1909).

4. Dragón policéfalo mitológico que, al cortarle una cabeza, crecían dos en su lugar.

5. Una de las mayores y más emblemáticas crisis financieras y sociales en la historia de los Estados Unidos.

6. Término acuñado por primera vez en 1931 por James Truslow Adams, en su libro The épic of América, donde se emparejaba este término a un imaginario de prosperidad individual basado en las oportunidades de la libertad individual y la meritocracia independientemente de la clase o el origen social. Este imaginario no se reducía simplemente al acceso de bienes a través de altos salarios y acumulación de dinero, sino que se constituía en un estilo de vida fundante del espíritu americano y al que todo ciudadano debía aspirar.

7. Superman, el "Hombre de Acero" uno de los primeros y quizás el mas icónico de los superhéroes de todos los tiempos, un alienígena huérfano que llega a la tierra con poderes sobrehumanos. Aparece en el $n^{\circ} 1$ de Action Cómic, en el año 1938, en Estados Unidos.

8. Batman, el "hombre murciélago" es otro de los superhéroes emblemáticos de occidente. Aparece en la edición de Junio de 1939, revista ${ }^{\circ} 27$ de Detective Cómic, Estados Unidos.

9. Ángela y Luciana Giussani, creadoras en el año 1962 del cómic de gran suceso Diabolik, en Milán, Italia.

10. El personaje Diabolik es un hábil ladrón con grandes conocimientos tecnológicos cuyos golpes espectaculares apuntan a los grandes bancos y a las élites mas favorecidas de su época.

11. Historias referidas a hombres lobo.

12. Historias referidas a hombres vampiros.

13. Espadas utilizadas por ninjas y guerreros japoneses.

14. Foto tomada por el fotógrafo sudafricano Kevin Carter, que le valió el premio Pulitzer. En ella se ve una niña hambrienta arrastrándose por el desierto sudanés al borde del colapso, mientras que detrás un buitre espera su muerte para devorarla. La campaña de indignación que le valió al fotógrafo por esta imagen, se tradujo en su suicidio.

Bibliografía

Barthes, R. (2008). Mitologías. Buenos Aires: Siglo XXI Editores.

Didi-Huberman, G. (2009). La Imagen Superviviente. Historia del arte y tiempo de los fantasmas según Aby Warburg. Madrid: Adaba Editores. 
Eco, U. (2008). Apocalípticos e Integrados. Barcelona: Fabula Tusquet Editores.

Harvey, D. (2008). La condición de la pos modernidad: investigación sobre los orígenes del cambio cultural. Editorial Amorrortu.

Morris, T. y Morris, M. (2010): Los súper héroes y la filosofía moderna. Barcelona: Blackie Books.

Ranciere, J. (2010). El espectador emancipado. Buenos Aires: Bordes Manantial.

Ranciere, J. (2011). El destino de las imágenes. Buenos Aires: Prometeo Libros.

Steimberg, O. (2013). Leyendo Historietas: Textos sobre relatos visuales y humor gráfico. Buenos Aires: Eterna Cadencia Editora.

Zizek, S. (2009). Sobre la violencia: seis reflexiones marginales. España: Paidos.

Artículos

Gombrich, E. (2003). Arte e ilusión. Estudio sobre la psicología de la representación pictórica. PDF Internet www.inicia.es

Villordo, A. (2012). Estética del cómic e imagen síntoma. Ponencia Congreso Latinoamericano, "Preguntas, abordajes y desafíos contemporáneos del campo comunicacional" CCOM - FSOC UBA, Bs As, Argentina ISBN 978-987-3810-21-3.

Villordo, A. (2015). Mito, Razón y pos razón: Un collage pos moderno. Revista Silogismo de Investigación. (CIDE) Volumen 1, n¹6 - ISSN: 1909-955X E - ISSN: 2422-0736.

Weber, M. (1919). Conferencia: La política como vocación.

Abstract: The article addresses the theme of aesthetic intensity and violence in the superhero comic. It is analyzed how injustice finds in the use of violence a means to resolve conflicts. In this context, the spectator attends a narrative charged with a monstrous aesthetic intensity. The graphic violence that is positioned as effective to appropriate the symbol (the punishment of the bad) constitutes a pure fiction; that the reader understands that it has no consequences in the real world.

Key words: violence - comics - superheroes

Resumo: O artigo aborda o tema da intensidade estética e da violência no comic do super- -herói. É analisado como a injustiça encontra no uso da violência um meio para resolver conflitos. Neste contexto, o espectador atende a uma narrativa encarregada de uma intensidade estética monstruosa. A violência gráfica que se posiciona como efetiva para se apropriar do símbolo (a punição do mal) constitui uma pura ficção; que o leitor entenda que não tem conseqüências no mundo real.

Palavras chave: violência - quadrinhos - super-heróis. 
[Las traducciones de los abstracts al inglés y portugués fueron supervisadas por el autor de cada artículo]

La imagen intolerable1 : Intensidad estética y violencia en el cómic de superhéroes fue publicado de la página 199 a página211 en Cuadernos del Centro de Estudios de Diseño y Comunicación №74 